\title{
Tinjauan Yuridis Mengenai Hak-Hak Khusus Pekerja Perempuan Berdasarkan Undang-Undang Nomor 13 Tahun 2003 tentang Ketenagakerjaan
}

\author{
Sonhaji \\ Fakultas Hukum, Universitas Diponegoro \\ E-mail : sonhajimuh19@gmail.com
}

\begin{abstract}
Women are naturally different from the men so that women have special rights granted while men are not given. Female workers / laborers likewise have special rights such as the right to leave miscarriage, the right to maternity leave, menstrual leave, the right to a shuttle if employed at night, and so forth. The special rights of female workers / laborers like these should be considered either by the company or by the workers / laborers women themselves. PT. Dian Andilta Utama is not yet fully apply the special rights of female workers / laborers, obstacles in implementing the special rights of female workers / laborers are in the application of the provision of menstrual leave and leave miscarriage, efforts to overcome obstacles in the implementation of the special rights of female workers / laborers are female workers / laborers should correctly understand the content of the employment agreement is given at the beginning will sign a cooperation agreement.
\end{abstract}

Keywords: Special Rights Of Women Workers, Act No. 13 of 2003

\begin{abstract}
Abstrak
Perempuan secara kodrati berbeda dengan laki-laki sehingga perempuan memiliki hak-hak khusus yang diberikan sedangkan laki-laki tidak diberikan.Pekerja/ buruh perempuan demikian pula memiliki hak-hak khusus seperti hak cuti keguguran kandungan, hak cuti melahirkan, hak cuti haid, hak mendapatkan antar jemput jika dipekerjakan pada malam hari, dan sebagainya.Hak-hak khusus pekerja/ buruh perempuan seperti ini sudah seharusnya diperhatikan baik oleh pihak perusahaan maupun oleh para pekerja/ buruh perempuan itu sendiri. PT. Dian Andilta Utama belum sepenuhnya menerapkan hak-hak khusus pekerja/ buruh perempuan, hambatan dalam menerapkan hak-hak khusus pekerja/ buruh perempuan adalah dalam penerapan pemberian cuti haid dan cuti keguguran, upaya mengatasi hambatan dalam penerapan hak-hak khusus pekerja/ buruh perempuan adalah pekerja/ buruh perempuan harus memahami secara benar isi dari perjanjian kerja yang diberikan pada saat awal akan menandatangani perjanjian kerja.
\end{abstract}

Kata kunci: Hak-Hak Khusus Pekerja Perempuan, Undang-Undang Nomor 13 Tahun 2003

\section{A. Pendahuluan}

Pekerjaan merupakan suatu hal penting yang harus dimiliki oleh setiap individu untuk mempertahankan hidupnya dengan cara memperoleh penghasilan. Setiap manusia juga mempunyai kebutuhan yang beraneka ragam yang harus dipenuhi, sehingga manusia dituntut untuk bekerja guna memenuhi kebutuhan hidupnya. Baik berupa pekerjaan yang 
diusahakan sendiri maupun bekerja pada orang lain. ${ }^{1}$ Kebutuhan itu bermacam-macam, mulai dari kebutuhan seperti makanan, pakaian, pendidikan dan lain-lain. Dari kebutuhan yang paling pokok sampai kebutuhan yang bisa dipenuhi setelah kebutuhan pokok terpenuhi. Oleh karena itu setiap individu harus bekerja dan mampu melakukan pekerjaan yaitu yang biasa disebut tenaga kerja.

Tenaga kerja adalah setiap orang yang mampu melakukan pekerjaan guna menghasilkan barang dan/ atau jasa, baik untuk memenuhi kebutuhan sendiri maupun untuk masyarakat. Tenaga kerja meliputi pegawai negeri, pekerja formal, pekerja informal, dan orang yang belum bekerja atau pengangguran. Dengan kata lain, pengertian tenaga kerja adalah lebih luas daripada pekerja/ buruh. ${ }^{2}$ Setiap tenaga kerja mempunyai hak dan kesempatan yang sama untuk memperoleh pekerjaan dan penghidupan yang layak tanpa membedakan jenis kelamin, suku, ras, agama, dan aliran politik sesuai dengan minat dan kemampuan tenaga kerja yang bersangkutan, termasuk perlakuan yang sama terhadap penyandang cacat.

Setiap tenaga kerja mempunyai hak dan kesempatan yang sama untuk memperoleh pekerjaan dan penghidupan yang layak tanpa membedakan jenis kelamin, suku, ras, agama, dan aliran politik sesuai dengan minat dan kemapuan tenaga kerja yang bersangkutan, termasuk perlakuan yang sama terhadap penyandang cacat. Kesamaan kesempatan dilaksanakan melalui penyediaan aksesibilitas baik oleh Pemerintah maupun masyarakat, yang dalam pelaksanaannya disertai dengan upaya peningkatan kesadaran dan tanggung jawab masyarakat termasuk terhadap keberadaan penyandang cacat. ${ }^{3}$

Sebagian besar lapangan kerja di perusahaan tidak membutuhkan keterampilan yang khusus, sehingga lebih banyak memberi peluang bagi tenaga kerja perempuan. Tuntutan ekonomi yang mendesak telah memberikan daya tarik yang kuat bagi tenaga kerja perempuan. Tidak hanya pada tenaga kerja perempuan yang sudah dewasa yang sudah dapat digolongkan pada angkatan kerja. Tetapi sering juga perempuan yang belum dewasa yang selayaknya masih harus belajar di bangku sekolah.

Tenaga kerja terdiri laki-laki dan perempuan, dan keduanya tentu memiliki

\footnotetext{
${ }^{1}$ H. Zainal Asikin, Dasar-Dasar Hukum Perburuhan, (Jakarta: PT Raja Grafindo Persada, 2004), halaman 1.

${ }^{2}$ Asri Wijayanti, Hukum Ketenagakerjaan Pasca Reformasi, (Jakarta: Sinar Grafika, 2009), halaman 1.

${ }^{3}$ Suhartoyo, Perlindungan Hukum Terhadap Pekerja/ Buruh Penyandang Disabilitas Di Indonesia, (Semarang: Fakultas Hukum Universitas Diponegoro, 2014), halaman 470.
} 
perbedaan-perbedaan. Tenaga kerja laki-laki dipandang lebih dominan dalam pekerjaan maupun di dalam kehidupan sehari-hari. Karena tugas utama laki-laki adalah sebagai pencari nafkah untuk anak istrinya, sedangkan perempuan tidak memiliki kewajiban yang sama seperti laki-laki. Perempuan juga berhak bekerja dan memperoleh penghasilan.

Perempuan memiliki hal-hal yang bersifat khusus dibandingkan dengan laki-laki, misalnya seperti mengalami haid, hamil, melahirkan, mengalami keguguran kandungan, hingga menyusui bayinya. Hal-hal semacam ini tentu tidak akan dialami oleh laki-laki, dengan kata lain hanya perempuan dialami oleh perempuan. Oleh karena itu perempuan harus mendapatkan perlakuan khusus serta perlindungan yang khusus yang tertuang dalam hak-hak khusus pekerja/ buruh perempuan.

Bagi tenaga kerja perempuan yang belum berkeluarga masalah yang timbul tentunya berbeda dengan yang sudah berkeluarga yang sifatnya lebih subyektif, meski secara umum kondisi objektif tidak ada perbedaan yang nyata. Perhatian yang benar bagi pemerintah dan masyarakat terhadap tenaga kerja terlihat pada beberapa peraturanperaturan yang memberikan kelonggaran-kelonggaran maupun larangan-larangan yang menyangkut seseorang perempuan secara umum seperti cuti hamil, kerja pada malam hari dan sebagainya.

Menyadari akan pentingnya pekerja/ buruh bagi perusahaan, pemerintah, dan masyarakat, maka perlu dilakukan pemikiran agar pekerja/ buruh dapat menjaga keselamatannya dalam menjalankan pekerjaan. Demikian pula perlu diusahakan ketenangan dan kesehatan pekerja/ buruh agar apa yang dihadapinya dalam pekerjaan dapat diperhatikan semaksimal mungkin sehingga kewaspadaan dalam menjalankan pekerjaan itu tetap terjamin. Pemikiran-pemikiran tersebut merupakan program kerja yang dalam praktik sehari-hari berguna untuk mempertahankan produktivitas dan kestabilan perusahaan. ${ }^{4}$

Hak-hak khusus pekerja/ buruh perempuan merupakan salah satu hal penting yang harus diperhatikan, baik oleh pemerintah maupun oleh perusahaan (pemberi kerja). Perempuan perlu mendapatkan perlindungan khusus, mengingat banyaknya kasus-kasus terhadap perempuan yang disebabkan karena kurangnya pengawasan terhadap penerapan

${ }^{4}$ Zaeni Asyhadie, Hukum Kerja Hukum Ketenagakerjaan Bidang Hubungan Kerja, (Jakarta: PT Raja Grafindo Persada, 2007), halaman 77. 
hak-hak khusus pekerja/ buruh perempuan di perusahaan. Mengingat perempuan juga memiliki fisik yang lebih rentan dibandingkan dengan laki-laki.

Hak-hak khusus pekerja/ buruh perempuan ditinjau dari Undang-Undang Nomor 13 Tahun 2003 tentang ketenagakerjaan, salah satunya ada di Pasal 82 yang membahas mengenai cuti melahirkan dan cuti keguguran. Cuti keguguran didalam Undang-Undang Nomor 13 Tahun 2003 Pasal 82 ayat (2) mengatakan bahwa "Pekerja/ buruh perempuan yang mengalami keguguran berhak memperoleh istirahat 1,5 (satu setengah) bulan atau sesuai dengan surat keterangan dokter kandungan atau bidan”. Namun terkadang cuti keguguran tidak diberikan oleh beberapa perusahaan, yang artinya perusahaan belum dapat menerapkan dengan baik apa yang sudah diatur didalam peraturan perundangundangan.

Haid, kehamilan, dan keguguran adalah hal yang umum dialami oleh semua perempuan. Sudah secara kodratnya semua perempuan mengalami hal ini. Hal ini yang menimbulkan adanya hak-hak khusus untuk pekerja/ buruh perempuan. Sehingga ada suatu kewajiban dari pemberi kerja atau pihak perusahaan untuk memenuhi hak-hak khusus pekerja/ buruh perempuan seperti yang tercantum pada Undang-Undang Nomor 13 Tahun 2003 tentang Ketenagakerjaan.

Di dalam beberapa perusahaan ada banyak pekerja/ buruh perempuan yang belum mengetahui dengan baik apa saja hak-haknya sebagai pekerja/ buruh perempuan. Hal ini disebabkan karena kurangnya sosialisasi mengenai hak-hak khusus pekerja/ buruh perempuan, atau bahkan karena kurangnya pengetahuan dari pekerja/ buruh perempuan itu sendiri dikarenakan tingkat pendidikan yang rendah. Hal semacam ini yang terkadang menjadi tidak terpenuhinya hak-hak sebagai pekerja/ buruh perempuan.

Keberadaan pekerja/ buruh perempuan di dalam dunia pekerjaan sudah sangatlah banyak, salah satunya keberadaan pekerja/ buruh perempuan di PT. Dian Andilta Utama. PT. Dian Andilta Utama adalah perusahaan yang bergerak dibidang beragam jasa konsultan keuangan yang berkantor pusat di Jakarta Timur. PT. Dian Andilta Utama memiliki 9 (sembilan) divisi jasa konsultan keuangan. Salah satunya adalah jasa konsultan penilaian, yang dalam hal ini ada kegiatan survey aset yang dilakukan oleh pekerja/ buruh di PT. Dian Andilta Utama. Sedangkan pelaku survey kebanyakan adalah pekerja/ buruh perempuan. 


\section{B. Metode Penelitian}

Metode pendekatan yang digunakan dalam penelitian ini adalah Metode pendekatan yuridis empiris yaitu pendekatan yang ditinjau dari sudut pandang peraturan-peraturandan hal-hal yang menyangkut hukum. Baik formil maupun non formil.Penelitian ini dilakukan terhadap bahan - bahan hukum sekunder yang meliputi peraturan perundang-undangan, tulisan dan pendapat para pakar hukum serta dokumen-dokumen yang berkaitan dengan penerapan hak-hak pekerja/ buruh perempuan. Pendekatan ini bertujuan untuk memperoleh pengetahuan empiris tentang hubungan dan pengaruh hukum terhadap masyarakat dengan jalan melakukan penelitian atau terjun langsung kedalam masyarakat atau lapangan untuk mengumpulkan data yang objektif. ${ }^{5}$

Penelitian ini merupakan penelitian dengan deskriptif analitis, yaitu penelitian yang menggambarkan peraturan perundang-undangan yang berlaku dan dikaitkan dengan fakta-fakta yang timbul dalam permasalahan ini. Pendekatan yang dilakukan ini bertujuan untuk memberikan data secara rinci mengenai hal-hal yang akan diteliti oleh penulis. Penelitian ini ditekankan pada aspek-aspek penerapan hak-hak pekerja/ buruh perempuan di PT. Dian Andilta Utama. Pendekatan ini lebih menekankan kepada aturan-aturan hukum, teori-teori hukum dan hukum positif di dalam masyarakat yang berkaitan dengan permasalahan yang akan diteliti serta dihubungkan dengan fakta-fakta yang ada di dalam masyarakat.

Untuk kesuksesan dari penelitian ini salah satunya ditunjang dengan penelitian di lapangan guna mendapatkan data yang diperlukan dalam menyusun penelitian ini, yaitu data primer dan data sekunder. Data primer diperoleh dengan cara wawancara secara langsung dengan para pekerja dan pemilik perusahaan, sedangkan data sekunder diperoleh dengan cara mengumpulkan, melihat, membaca, menyelesaikan, dan meneiliti peraturan perundang-undangan, buku-buku, serta sumber bacaan lainnya yang berkaitan dengan masalah yang akan diteliti.

Data-data yang telah diperoleh melalui penelitian di lapangan, kemudian disusun secara lengkap, sistematis, benar dan konsisten. Kemudian data yang telah dikumpulkan akan dianalisa secara kualitatif, dengan tujuan untuk mencapai kejelasan masalah yang

\footnotetext{
${ }^{5}$ P. Joko Subagyo, Metode Penelitian Dalam Teori dan Praktek, (Jakarta : Rhineka Cipta, 1991), Halaman 91.
} 
akan dibahas. Semua data yang terkumpul diedit, diolah dan disusun secara sistematis untuk selanjutnya disajikan.

Data-data yang telah diperoleh kemudian akan diteliti secara rinci.

\section{Pembahasan}

Kesehatan kerja adalah adanya jaminan kesehatan pada saat melakukan suatu pekerjaan. Kesehatan kerja bertujuan untuk peningkatan dan pemeliharaan derajat kesehatan fisik, mental dan sosial setinggi-tingginya bagi pekerja/ buruh di semua jenis pekerjaan.

Kesehatan kerja diatur di dalam Undang-Undang Nomor 13 Tahun 2003 tentang ketenagakerjaan, berikut perinciannya:

\section{- Pasal 86}

(1) Setiap pekerja/ buruh mempunyai hak untuk memperoleh perlindungan atas :

a. Keselamatan dan kesehatan kerja

b. Moral dan kesusilaan

c. Perlakuan yang sesuai dengan harkat dan martabat serta nilai-nilai agama

(2) Untuk melindungi keselamatan pekerja/ buruh guna mewujudkan produktivitas kerja yang optimal diselenggarakan upaya keselamatan dan kesehatan kerja.

\section{- Pasal 87}

Setiap perusahaan wajib menerapkan sistem manajemen keselamatan dan kesehatan kerja yang terintegrasi dengan sistem manajemen perusahaan.

Ada pula mengenai jaminan kesehatan, PT. Dian Andilta Utama telah bekerjasama kepada BPJS Ketenagakerjaan untuk menjamin kesehatan para pekerja/ buruhnya. Hal ini dikarenakan pentingnya kesehatan kerja didalam kelangsungan suatu perusahaan. BPJS Ketenagakerjaan adalah badan hukum publik yang bertanggung jawab kepada presiden dan berfungsi menyelenggarakan program jaminan hari tua, jaminan pensiun dan jaminan kecelakaan kerja bagi seluruh pekerja Indonesia termasuk orang asing yang bekerja paling cepat 6 bulan di Indonesia. ${ }^{6}$ Atau dapat juga dikatakan sebagai program publik yang memberikan perlindungan bagi tenaga kerja untuk mengatasi resiko sosial ekonomi tertentu dan penyelenggaraannya menggunakan mekanisme asuransi sosial. ${ }^{7}$

${ }^{6}$ Diakses dari www.wikipedia.orgpada tanggal 25 november 2016 pukul 09.39

${ }^{7}$ Diakses dari www.wikipedia.orgpada tanggal 25 November 2016 pada pukul 10.03 
Para pekerja/ buruh baik perempuan maupun laki-laki dapat menggunakan BPJS Ketenagakerjaan yang diberikan oleh PT. Dian Andilta Utama sebagai fasilitas.Tujuan utama BPJS Ketenagakerjaan adalah untuk kesejahteraan para pekejanya sendiri.PT. Dian Andilta Utama akan memberikan bantuan kepada pekerja/ buruh jika mengalami kondisi :

a. Pekerja/ buruh, istri/ suami pekerja/ buruh, anak pekerja/ buruh meninggal

b. Pekerja/ buruh, istri/ suami pekerja/ buruh, anak pekerja/ buruh menderita sakit dan harus menjalani rawat inap lebih dari 3 hari

Jumlah bantuan yang akan diberikan kepada pekerja/ buruh yang mengalami suatu musibah seperti meninggal ataupun sakit yang mengharuskanm rawat inap ditentukan oleh PT. Dian Andilta Utama ditentukan berdasarkan kebijakan PT. Dian Andilta Utama yang bersifat sukarela.

Berdasarkan dari hasil penelitian di lapangan dan wawancara dapat diketahui bahwa kesehatan kerja bagi pekerja/ buruh perempuan pada PT. Dian Andilta Utama adalah : 8

a. PT. Dian Andilta Utama memberikan santunan apabila pekerja/ buruh perempuan mengalami musibah baik berupa kematian ataupun rawat inap.

b. Pekerja/ buruh perempuan berhak memanfaatkan fasilitas yang diberikan PT. Dian Andilta Utama berupa BPJS Ketenagakerjaan.

Kesimpulannya pemberian jaminan kesehatan kerja bagi pekerja/ buruh khususnya pekerja/ buruh perempuan telah dilaksanakan dengan baik dan telah sesuai dengan peraturan perundang-undangan dan perjanjian kerja yang dibuat antara pemberi kerja dan pekerja/ buruh.

Jam kerja adalah waktu untuk melakukan pekerjaan, yang dapat dilaksanakan pada malam hari maupun pada siang hari.Pengusaha/ pemberi kerja dalam meberikan waktu kerja tidak boleh bertentangan dengan peraturan yang berlaku, misalnya seperti mempekerjakan pekerja perempuan pada malam hari tanpa adanya perlindungan seperti yang sudah ditetapkan di dalam undang-undang. Waktu kerja yang diperbolehkan bagi seorang pekerja/ buruh sudah ditentukan dalam Undang-Undang Ketenagakerjaan Nomor 13 Tahun 2003.Dalam Pasal 77

${ }^{8}$ Nurul Farida, Wawancara bagian Research And Development, (Jakarta, 23 November 2016). 
Undang-Undang Nomor 13 Tahun 2003 dijelaskan bahwa setiap pengusaha wajib melaksanakan ketentuan waktu kerja, apabila dilakukan penyimpangan pada jam kerja tersebut, maka pengusaha harus mengajukan izin dari lembaga yang berwenang dan harus melakukan pembayaran/ kompensasi sesuai peraturan tentang kerja lembur dan upah kerja lembur.

Waktu kerja yang ditetapkan Undang-Undang Nomor 13 Tahun 2003 Pasal 77 ayat (2) adalah sebagai berikut :

a. 7 (tujuh) jam 1 (satu) hari dan 40 (empat puluh) jam 1 (satu) minggu untuk 6 (enam) hari kerja dalam 1 (satu) minggu

b. 8 (delapan) jam 1 (satu) hari dan 40 (empat puluh) jam 1 (satu) minggu untuk 5 (lima) hari kerja dalam 1 (satu) minggu

Penyimpangan dari ketentuan ini diatur oleh Pasal 78 Undang-Undang Nomor 13 Tahun 2003, dengan syarat-syarat sebagai berikut :

1) Ada persetujuan pekerja/buruh yang bersangkutan

2) Waktu kerja lembur hanya dapat dilakukan paling banyak 3 (tiga) jam dalam 1 (satu) hari dalam 14 (empat belas) jam dalam 1 (satu) minggu

3) Pengusaha yang mempekerjakan pekerja/ buruh melebihi waktu kerja, maka wajib membayar upah kerja lembur sesuai dengan peraturan

Di dalam Perjanjian Kerja PT. Dian Andilta Utama, waktu kerja diatur dalam Pasal 4, yang berisi: ${ }^{9}$

1. PIHAK PERTAMA menetapkan hari kerja untuk PIHAK KEDUA adalah 5 (lima) hari seminggu atau 40 (empat puluh) jam kerja seminggu.

2. 5 (lima) hari kerja seminggu adalah dari hari senin sampai dengan hari jumat, jam kerjanya adalah 8 (delapan) jam sehari, dengan perincian sebagai berikut:

- Senin s/d Kamis:

Jam Kerja08.00 s/d 17.00

Jam Istirahat $12.00 \mathrm{~s} / \mathrm{d} 13.00$

\footnotetext{
${ }^{9}$ Perjanjian Kerja PT. Dian Andilta Utama, Halaman 3.
} 
- Jumat:

Jam Kerja07.30 s/d 17.00

Jam istirahat $11.30 \mathrm{~s} / \mathrm{d} 13.00$

3. Jam Kerja ini hanya berlaku untuk karyawan PT. Dian Andilta pada umumnya.

4. Jam kerja untuk bagian keamanan dan office boy diatur berbeda dengan jam kerja bagi karyawan pada umumnya, jam kerjanya akan disesuaikan dengan jadwal kerja pada unit kerjanya.

Penjelasan dari Pasal 4 perjanjian kerja PT. Dian Andilta Utama mengenai waktu kerja di PT. Dian andilta Utama adalah : ${ }^{10}$

1. Hari kerja pada PT. Dian Andilta Utama adalah 5 (lima) hari dalam seminggu, yaitu pada hari senin sampai dengan jumat.

2. Hari minggu dan sabtu pekerja diliburkan dan diperbolehkan tidak masuk kerja, kecuali ada ketentuan lain dari PT. Dian Andilta Utama.

3. Jam kerja yang ditentukan untuk karyawan PT. Dian Andilta pada umumnya adalah 40 (empat puluh) jam kerja dalam seminggu yang dibagi dalam 8 (delapan) jam kerja dalam sehari.

4. Jam kerjanya dengan perincian sebagai berikut :

a. Dari hari senin sampai dengan kamis, pekerja/ buruh masuk pukul 08.00 pagi dan diperbolehkan pulang pada pukul 17.00 sore, dengan diberi waktu istirahat dari pukul 12.00 sampai dengan 13.00 siang. Jadi, bekerja selama 8 jam dan istirahat selama 1 jam dalam sehari.

b. Khusus untuk hari jumat, pekerja/ buruh diharuskan masuk lebih awal yaitu pada pukul 07.00 pagi dikarenakan istirahat hari jumat lebih lama 30 menit dibanding hari biasanya. Untuk umat muslim yang laki-laki ada kewajiban untuk menjalani kewajiban shalat jumat. Jam pulang sama dengan hari-hari kerja biasanya.

5. Jam kerja yang ditetapkan ini hanya berlaku untuk karyawan PT. Dian Andilta pada umumnya, terkecuali untuk bagian keamanan.

\footnotetext{
${ }^{10}$ Hevi Mustikasari, Wawancara bagian umum PT. Dian Andilta Utama, (Jakarta, 23 November 2016)
} 
6. Bagian keamanan di PT. Dian Andilta Utama memiliki 3 (tiga) pergantian jam kerja (shift) dimana masing-masing shift memiliki 8 jam kerja, dengan perincian waktu sebagai berikut :

Shift Pagi (I) $\quad: 08.00 \mathrm{~s} / \mathrm{d} 16.00$

Shift Sore (II) $\quad: 16.00 \mathrm{~s} / \mathrm{d} 00.00$

Shift Malam (III) : $00.00 \mathrm{~s} / \mathrm{d} 08.00$

7. Bagian office boy di PT. Dian Andilta Utama memiliki waktu kerja 8 (delapan) jam kerja sehari, dengan jam kerja berbeda dengan karyawan lainnya, dengan perincian waktu sebagai berikut :

- Senin s/d Kamis:

Jam Kerja 07.00 s/d 16.00

Jam Istirahat $12.00 \mathrm{~s} / \mathrm{d} 13.00$

- Jumat:

Jam Kerja 06.30 s/d 16.00

Jam Istirahat $11.30 \mathrm{~s} / \mathrm{d} 13.00$

Berdasarkan dari hasil penelitian di lapangan dan wawancara dapat diketahui bahwa waktu kerja bagi pekerja/ buruh perempuan pada PT. Dian Andilta Utama adalah $:^{11}$

a. Pekerja/ buruh perempuan di PT. Dian Andilta Utama bekerja sesuai dengan jam kerja yang sudah ditetapkan didalam perjanjian kerja yang dibuat dan ditanda tangani pada saat awal, berikut perinciannya:

1. Untuk karyawan perempuan pada umumnya

- Senin s/d Kamis:

Jam Kerja 08.00 s/d 17.00

Jam Istirahat $12.00 \mathrm{~s} / \mathrm{d} 13.00$

- Jumat:

Jam Kerja 07.30 s/d 17.00

Jam istirahat $\quad 11.30 \mathrm{~s} / \mathrm{d} 13.00$

${ }^{11}$ Mirza riskia, Wawancara Surveyor PT. Dian Andilta Utama, (Jakarta, 23 November 2016). 
b. Pekerja/ buruh perempuan di PT. Dian Andilta Utama khususnya bagian surveyor yang sering melakukan tugas pekerjaan keluar kantor juga diberikan transportasi dan akomodasi perjalanan.

c. Pekerja/ buruh perempuan di PT. Dian Andilta Utama tidak dipekerjakan pada malam hari sehingga PT. Dian Andilta Utama tidak menyediakan fasilitas antar jemput untuk pekerja/ buruh.

Kesimpulannya waktu kerja bagi pekerja/ buruh perempuan telah dilaksanakan dengan baik dan telah sesuai dengan peraturan perundang-undangan dan perjanjian kerja yang dibuat anatara pemberi kerja dan pekerja/ buruh.

Pekerja/ buruh perempuan secara kodratnya mempunyai karakteristik yang berbeda dengan laki-laki yang tentunya perlu mendapatkan perhatian khusus dari perusahaan tempatnya bekerja.Untuk menghindari pekerja/ buruh perempuan dari berbagai pengaruh buruk yang timbul akibat dari keterkaitan mereka, maka dari segi itu pemerintah Indonesia menetapkan peraturan perundang-undangan untuk melindungi pekerja/ buruh perempuan.Perlindungan terhadap pekerja/ buruh perempuan mengenai cuti haid merupakan hal yang sangat penting jika pekerja/ buruh perempuan mengalami sakit pada saat masa haid.

Pasal 81 Undang-Undang Nomor 13 Tahun 2003 tentang Ketenagakerjaan mengatur mengenai masalah perlindungan dalam masa haid.Perlindungan terhadap pekerja/ buruh perempuan yang dalam masa haid tidak wajib bekerja pada hari pertama dan kedua pada waktu haid dengan upah penuh.

Di dalam Perjanjian Kerja PT. Dian Andilta Utama, cuti haid diatur dalam Pasal 10, yang berisi: ${ }^{12}$

1. Pekerja perempuan yang mengalami sakit selama masa haid dan memberitahukan hal tersebut kepada PIHAK PERTAMA maka pekerja/ buruh perempuan tersebut tidak wajib bekerja pada hari pertama masa haid saja.

\footnotetext{
${ }^{12}$ Perjanjian Kerja PT. Dian Andilta Utama, Halaman 6.
} 
Artinya pekerja/ buruh perempuan yang sedang mengalami sakit pada saat masa haid diperbolehkan tidak masuk bekerja pada hari pertama haid, dengan tetap memberitahukan kepada atasannya terlebih dahulu baik melalui alat komunikasi maupun secara langsung. ${ }^{13}$

Sedangkan menurut hasil penelitian lapangan dan wawancara dengan pekerja/ buruh perempuan, sebagian mengatakan jika cuti haid sering kali tidak diberikan dengan alasan tidak perlu. ${ }^{14}$ Ada juga pekerja/ buruh perempuan yang tidak mengetahui mengenai adanya hak untuk mengajukan cuti haid pada saat hari pertama masa haid jika mengalami rasa sakit. ${ }^{15}$ Masih banyak pekerja/ buruh perempuan yang belum mengetahui mengenai adanya cuti haid seperti yang sudah diatur di dalam peraturan perundang-undangan. Hal ini tentu berbeda dengan apa yang sudah diatur di dalam perjanjian kerja yang dibuat oleh pekerja/ buruh dan pemberi kerja/ perusahaan pada saat awal bekerja.

Hal ini disebabkan salah satunya karena kurangnya perhatian pekerja/ buruh perempuan terhadap adanya hak untuk mengajukan cuti haid. Jika pada saat masa haid pekerja/ buruh perempuan tidak mengalami sakit pada saat masa haid maka bekerja pada saat masa haid tiba tidak menjadi masalah, namun akan bermasalah jika pekerja/ buruh perempuan yang mengalami sakit pada saat awal masa haid maka dikhawatirkan akan berbahaya bagi kesehatan pekerja/ buruh perempuan itu sendiri.

Kesimpulannya, hak khusus mengenai cuti haid belum sepenuhnya sesuai dengan peraturan perundangan yang berlaku.

Melahirkan adalah suatu kejadian yang pasti akan dialami oleh setiap perempuan yang sudah berkeluarga. Seorang perempuan secara kodrati akan menikah dan akan mempunyai keturunan. Masa kehamilan perempuan akan dialami selama 9 bulan lamanya, dan masa pemulihan setelah melahirkan baik secara operasi (caesar) maupun secara normal. Melahirkan juga merupakan salah satu pembeda antara laki-laki dan perempuan, karena laki-laki secara kodrati tidak bisa melahirkan.

\footnotetext{
${ }^{13}$ Andari Setiyawati, Wawancara bagian Administrasi Umum PT. Dian Andilta Utama, (Jakarta, 23 November 2016).

${ }^{14}$ Sri Lestari, Wawancara bagian Business Development PT. Dian Andilta Utama, (Jakarta, 23 November 2016 ).

${ }^{15}$ Tiwi, Wawancara bagian Corporate Secretary PT. Dian Andilta Utama, (Jakarta, 23 November 2016).
} 
Pada Pasal 82 Undang-Undang Nomor 13 Tahun 2003 tentang Ketenagakerjaan mengatur masalah cuti melahirkan dijelaskan bahwa perlindungan cuti melahirkan selama 1,5 bulan sebelum saatnya melahirkan dan 1,5 bulan sesudah melahirkan dengan upah penuh. Artinya pekerja/ buruh perempuan yang akan mengajukan cuti melahirkan selama waktu yang sudah ditentukan akan mendapatkan upah penuh tanpa adanya potongan-potongan.

Di dalam Perjanjian Kerja PT. Dian Andilta Utama, cuti melahirkan diatur dalam Pasal 8, yang berisi: ${ }^{16}$

1. Pekerja/ buruh perempuan berhak mendapatkan cuti melahirkan selama $1 \frac{1}{2}$ bulan sebelum melahirkan dan selama $1 \frac{1}{2} 2$ bulan setelah melahirkan.

2. Diperbolehkan mengajukan cuti lebih dari apa yang sudah ditentukan di Pasal 8 ayat (1) apabila ada surat keterangan tertulis dari dokter kandungan atau bidan yang merawatnya dengan tetap mendapatkan upah penuh.

3. Cuti melahirkan diajukan paling lama 1 minggu sebelumnya dengan membawa surat keterangan dokter kandungan atau bidan.

Artinya PT. Dian Andilta Utama memperbolehkan adanya pengajuan pengambilan hak cuti melahirkan selama $1 \frac{1}{2}$ bulan sebelum melahirkan dan selama $1 \frac{1}{2}$ bulan setelah melahirkan. Diperbolehkan mengajukan cuti lebih dengan adanya surat keterangan dokter/ bidan yang merawatnya yang menyatakan bahwa pekerja/ buruh perempuan masih memerlukan istirahat. ${ }^{17}$

Sedangkan menurut hasil penelitian di lapangan dan wawancara kepada pekerja/ buruh perempuan, cuti melahirkan sudah diberikan oleh PT. Dian Andilta Utama sesuai dengan apa yang sudah diatur di dalam perjanjian kerja yang dibuat antara pemberi kerja dan pekerja/ buruh. $^{18}$

Kesimpulannya, hak khusus mengenai cuti melahirkan telah sesuai dengan peraturan perundangan dan perjanjian kerja antara PT. Dian Andilta Utama dengan Pekerja/ buruh.

\footnotetext{
${ }^{16}$ Perjanjian Kerja Pt. Dian Andilta Utama, Halaman 5.

${ }^{17}$ Nurul Farida, Wawancara bagian Research And Development, (Jakarta, 23 November 2016).

${ }^{18}$ Mirza Riskia, Wawancara surveyor, (Jakarta, 23 November 2016).
} 
Pekerja/ buruh perempuan yang mengalami keguguran kandungan juga berhak memperoleh istirahat selama 1,5 bulan atau sesuai dengan Surat Keterangan dokter kandungan atau bidan, seperti yang tercantum pada Pasal 82 Undang-Undang Nomor 13 Tahun 2003.

Di dalam Perjanjian Kerja PT. Dian Andilta Utama, cuti gugur kandungan diatur dalam Pasal 9, yang berisi : ${ }^{19}$

1. Apabila pekerja/ buruh perempuan mengalami keguguran kandungan, maka berhak mengajukan istirahat selama 1 minggu setelah mengalami keguguran, sesuai dengan keterangan dokter kandungan atau bidan dan tetap mendapatkan upah secara penuh.

Sedangkan menurut hasil penelitian lapangan dan wawancara pekerja/ buruh perempuan, pekerja perempuan yang mengalami keguguran kandungan diperbolehkan mengajukan cuti keguguran dengan lama waktu 1 minggu serta menggunakan surat keterangan dokter yang merawatnya. ${ }^{20}$

Kesimpulannya, hak khusus mengenai cuti gugur kandungan belum sepenuhnya sesui dengan peraturan perundangan yang berlaku, karena lama waktu yang diberikan untuk cuti keguguran kandungan hanya 1 minggu sehingga menyalahi aturan yang telah ditetapkan oleh pemerintah.

Dalam pelaksanaannya, penerapan hak-hak khusus bagi pekerja/ buruh perempuan di PT. Dian Andilta Utama mengalami beberapa hambatan/ kendala yang dihadapi oleh PT. Dian Andilta Utama tersebut dan pekerja/ buruh perempuannya.Banyak pekerja/ buruh perempuan yang tidak mengetahui adanya hak mengenai cuti haid yang sudah diatur di perjanjian kerja dan juga peraturan perundang-undangan.Salah satunya hal ini disebabkan karenanya kurangnya sosialisasi mengenai adanya cuti haid untuk pekerja/ buruh perempuan di PT. Dian Andilta Utama.Dapat juga disebabkan karena kurangnya perhatian para pekerja/ buruh perempuan di PT. Dian Andilta Utama terhadap adanya hak cuti haid yang diberikan oleh pihak perusahaan selama 1 hari jika mengalami sakit.

Banyak pekerja/ buruh yang mengeluhkan mengenai waktu cuti keguguran yang terlalu

\footnotetext{
${ }^{19}$ Perjanjian Kerja PT. Dian Andilta Utama, Halaman 6.

${ }^{20}$ Sri Lestari, Wawancara bagian Business And Development PT. Dian Andilta Utama, (Jakarta, 23 November 2016).
} 
singkat, karena PT. Dian Andilta Utama hanya memberikan waktu istirahat selama 1 minggu jika mengalami keguguran, padahal seharusnya 1,5 bulan waktu istirahat yang semestinya diberikan menurut aturan perundangan yang berlaku. Menurut sebagian pekerja/ buruh perempuan hal ini dirasa kurang efektif karena belum sesuai dengan peraturan perudangundangan yang berlaku.Sebagian pekerja/ buruh mengaku belum mengetahui mengenai diperbolehkannya cuti pada saat tejadi keguguran.Sangat disayangkan karena terlalu kurangnya komunikasi yang baik antara pengusaha/ pemberi kerja dengan pekerja/ buruh perempuan di PT. Dian Andilta Utama.

PT. Dian Andilta Utama mengakui bahwa belum pernah melakukan sosialisasi secara langsung kepada para pekerja/ buruh perempuan PT. Dian Andilta Utama mengenai hak cuti haid dan cuti keguguran.Karena seringnya menganggap cuti haid dan cuti keguguran sebagai hal yang tidak biasa sehingga beranggapan kalau hal ini tidak perlu diberikan kepada pekerja/ buruh perempuan di PT. Dian Andilta Utama.

Upaya-upaya untuk mengatasi hambatan-hambatan/ kendala-kendala dalam menerapkan hak-hak khusus bagi pekerja/ buruh perempuan di PT. Dian Andilta Utama adalah pekerja/ buruh perempuan harus memahami secara benar isi dari perjanjian kerja yang telah ditanda tangani pada saat awal bekerja. Supaya tidak terjadi ketidaktahuan mengenai adanya cuti haid dan cuti keguguran yang sebetulnya sangat penting untuk diterapkan kepada pekerja/ buruh perempuan.PT. Dian Andilta Utama harus mengupayakan untuk memberikan sosialisasi kepada pekerja/ buruh perempuan mengenai hak-hak yang seharusnya didapatkan oleh pekerja/ buruh perempuan.Karena hal ini merupakan hal yang sangat penting untuk diterapkan, karena berkaitan dengan kesehatan pekerja/ buruh perempuan itu sendiri.

\section{Simpulan}

Berdasarkan hasil dari penelitian yang dilaksanakan di PT. Dian Andilta Utama dapat ditarik beberapa kesimpulan sebagai berikut: PT. Dian Andilta Utama belum sepenuhnya menerapkan hak-hak khusus bagi pekerja/ buruh perempuan. Kesehatan kerja telah dilaksanakan dengan baik sesuai dengan peraturan perundang-undangan yang berlaku. Waktu kerja yang diberikan perusahaan telah memenuhi standard yang ditetapkan oleh peraturan perundang-undangan. Sedangkan cuti melahirkan yang diberikan oleh perusahaan terhadap pekerja/ buruh perempuan juga telah sesuai dengan peraturan perundang-undangan yang berlaku. Sedangkan cuti keguguran dan cuti haid belum sesuai dengan peraturan perundang- 
undangan yang berlaku.

Hambatan-hambatan menerapkan hak-hak khusus pekerja/ buruh perempuan dalam penerapan pemberian cuti haid dan cuti keguguran adalah kurangnya kesadaran perusahaan dalam memenuhi ketentuan undang-undang nomor 13 tahun 2003 dan kurangnya kesadaran dari pekerja/ buruh perempuan untuk mau memahami mengenai pentingnya cuti haid dan cuti keguguran sehingga bersikap acuh tak acuh terhadap hak yang seharusnya diperoleh. Waktu cuti yang diberikan oleh perusahaan belum sesuai dengan undang-undang ketenagakerjaan sehingga oleh sebagian pekerja/ buruh perempuan dianggap terlalu singkat. Kurangnya sosialisasi mengenai hak cuti haid dan cuti keguguran kepada pekerja/ buruh sehingga menyebabkan banyak pekerja/ buruh yang belum memahami mengenai adanya hak cuti haid dan keguguran yang diberikan oleh perusahaan.

Upaya mengatasi hambatan dalam penerapan hak-hak khusus pekerja/ buruh perempuan adalah pekerja/ buruh perempuan harus memahami secara benar isi dari perjanjian kerja yang diberikan pada saat awal akan menandatangani perjanjian kerja. Hal ini dimaksudkan agar pekerja/ buruh perempuan dapat memahami secara rinci hak-hak dan tanggung jawab apa saja yang akan didapatkan jika bekerja di PT. Dian Andilta Utama. Perusahaan sebaiknya mengadakan sosialisasi/ penyuluhan kepada para pekerja/ buruh dapat memahami lebih rinci mengenai hak-hak yang akan diberikan oleh perusahaan.

\section{Daftar Pustaka}

Asikin, Zainal, Dasar-Dasar Hukum Perburuhan. PT. Raja Grafindo Persada, Jakarta. 2004.

Asyhadie, Zaeni, Hukum Kerja Hukum Ketenagakerjaan Bidang Hubungan Kerja. PT. Raja Grafindo, Jakarta. 2007.

Suhartoyo, Perlindungan Hukum Terhadap Pekerja/ Buruh Penyandang Disabilitas Di Indonesia. Jurnal Masalah Hukum, Fakultas Hukum Universitas Diponegoro Semarang. Semarang. 2014.

Subagyo, Joko, Metode Penelitian Dalam Teori dan Praktek. Rhineka Cipta, Jakarta. 1991. Wijayanti, Asri, Hukum Ketenagakerjaan Pasca Reformasi. Sinar Grafika, Jakarta. 2009. Undang-Undang Nomor 13 tahun 2003 tentang Ketenagakerjaan 